\title{
Małopłytkowość u chorego ze sztuczną zastawką aortalną leczonego heparyną drobnocząsteczkową
}

\author{
Thrombocytopenia in a patient with a mechanical aortic valve treated \\ with low-molecular-weight heparin
}

\author{
Iwona Gorczyca-Michta ${ }^{1}$, Beata Wożakowska-Kapłon ${ }^{1,2}$ \\ ${ }^{1}$ K Klinika Kardiologii i Elektroterapii Świętokrzyskiego Centrum Kardiologii w Kielcach \\ ${ }^{2}$ Wydział Lekarski i Nauk o Zdrowiu Uniwersytetu Jana Kochanowskiego w Kielcach
}

\section{Streszczenie}

Powikłania zakrzepowo-zatorowe, takie jak zatorowość systemowa i zakrzepica sztucznej zastawki, często występują po implantacji sztucznej zastawki, a korzyści z leczenia przeciwzakrzepowego muszą być równoważone z ryzykiem powikłań krwotocznych. Postępowanie u chorego z małopłytkowością i bezwzględnym wskazaniem do antykoagulacji, takim jak sztuczna zastawka, wymaga indywidualizacji leczenia uwzględniającego przede wszystkim bardzo wysokie ryzyko powikłań zakrzepowo-zatorowych.

Słowa kluczowe: trombocytopenia, sztuczna zastawka serca, powikłania zakrzepowo-zatorowe

Folia Cardiologica 2016; 11, 3: 233-235

\section{Wstęp}

Długotrwałe leczenie doustnymi antykoagulantami istotnie obniża ryzyko powikłań zakrzepowo-zatorowych u chorych z wszczepionymi sztucznymi zastawkami serca. Stosowanie doustnych antykoagulantów w tej grupie powinno prowadzić do osiągnięcia wartości międzynarodowego współczynnika znormalizowanego (INR, international normalized ratio) między 2,5 a 4,0 - zależnie od trombogenności zastawki i obecności czynników ryzyka powikłań zakrzepowo-zatorowych [1]. Doustne antykoagulanty zaleca się u wszystkich chorych po wszczepieniu sztucznej zastawki do końca życia (klasa I, poziom wiarygodności danych B) [1]. Dożylne przyjmowanie heparyny niefrakcjonowanej (UFH, unfractionated heparin), monitorowane na podstawie wydłużenia czasu częściowej tromboplastyny po aktywacji do 1,5-2-krotnej wartości kontrolnej, pozwala na szybkie osiągnięcie efektu przeciwzakrzepowego przed wzrostem INR do wartości docelowych. Heparyny drobnocząsteczkowe (LMWH, low-molecular-weight heparin), które stosowano w krótkich badaniach obserwacyjnych, prawdopodobnie wywieraja skuteczny i stabilny efekt antykoagulacji [2]. Jednak ich stosowanie nie jest objęte wskazaniami rejestracyjnymi. W przypadkach stosowania LMWH wskazane jest monitorowanie aktywności anty-Xa.

\section{Opis przypadku}

Pacjent w wieku 74 lat, po implantacji sztucznej zastawki aortalnej (Saint Jude Medical 21 mm) w 2003 roku z powodu ciężkiej stenozy, z nadciśnieniem tętniczym, niewydolnością serca w II klasie według New York Heart Association (NYHA) i cukrzycą typu 2, został skierowany do kliniki kardiologii w celu ustalenia optymalnego postępowania w profilaktyce zakrzepowo-zatorowej. Chory był hospitalizowany klinice hematologii z powodu podejrzenia

Adres do korespondencji: dr n. med. Iwona Gorczyca-Michta, I Klinika Kardiologii i Elektroterapii, Świętokrzyskie Centrum Kardiologii,

ul. Grunwaldzka 45, 25-736 Kielce, e-mail: iwona.gorczyca@interia.pl 
nowotworu mieloproliferacyjnego - mielofibrozy. W trakcie hospitalizacji w klinice hematologii, z powodu małopłytkowości (liczba płytek krwi [PLT, platelets] $22000 \mathrm{~K} / \mu \mathrm{l}$ ), zaprzestano leczenia antagonistą witaminy K (VKA, vitamin $K$ antagonist) i w ramach prewencji powikłań zakrzepowo-zatorowych chory otrzymywał dalteparynę w dawce 2500 jm. (przez 2 miesiące). Dwa tygodnie przed przyjęciem do kliniki kardiologii dalteparynę odstawiono ze względu na utrzymującą się małopłytkowość (liczba PLT $18000 \mathrm{~K} / \mu \mathrm{l})$. W chwili przyjęcia do kliniki chory nie był poddany profilaktyce powikłań zakrzepowo-zatorowych. Jego stan był stabilny. Wartość INR przy przyjęciu wynosiła 0,9. Włączono leczenie VKA, monitorując INR; nie stosowano pomostowej terapii heparyną ze względu na małopłytkowość. W badaniu echokardiograficznym nie uwidoczniono cech dysfunkcji sztucznej zastawki aortalnej. Piątego dnia terapii VKA osiągnięto terapeutyczny INR. Wartości PLT w trakcie hospitalizacji wynosiły od 19000 do $27000 \mathrm{~K} / \mu \mathrm{l}$. Chorego wypisano w stanie stabilnym, z zaleceniem stosowania acenokumarolu w dawce $1 \mathrm{mg} /$ dobę oraz dalszej kontroli hematologicznej.

\section{Omówienie}

U omawianego chorego trudność w prowadzeniu skutecznego leczenia przeciwzakrzepowego wynikała z bezobjawowej, ale postępującej małopłytkowości. W chwili odstawienia VKA liczba PLT wynosiła $25 \mathrm{~K} / \mu \mathrm{l}$. Z powodu obecności sztucznej zastawki w ujściu aortalnym włączono do leczenia dalteparynę. W wyniku zastosowanego leczenia obserwowano postępujące obniżenie liczby PLT. Trudno ustalić jednoznacznie, czy u tego pacjenta spadek liczby PLT był spowodowany nowotworem mieloproliferacyjnym, czy też był skutkiem zastosowania dalteparyny. Rozpoznanie małopłytkowości poheparynowej (HIT, heparin-induced thrombocytopenia) u tego chorego jest prawdopodobne, choć trudne do zweryfikowania ze względu wyjściową niską liczbę PLT. Małopłytkowość poheparynowa typu I powoduje zwykle łagodne obniżenie liczby PLT (rzadko poniżej $100 \mathrm{~K} / \mu \mathrm{l}$ ), natomiast w przebiegu HIT typu II liczba PLT istotnie się zmniejsza, osiągając wartość 50-80 K/ $\mu$ l lub obniżenie liczby PLT o co najmniej 30-50\% [3]. Małopłytkowość poheparynowa jest najczęstszą przyczyną małopłytkowości polekowej. Przeciwciała anty-HIT (przeciw kompleksom hepary- na-czynnik płytkowy F4) powstają u około 8\% chorych przyjmujących heparynę. U omawianego chorego liczba PLT obniżyła się o 28\% wskutek włączenia dalteparyny. Jednak wyjściowo znacznie obniżona liczba PLT utrudniła ocenę istotności różnicy liczby PLT przed włączeniem LMWH i po tym fakcie. Możliwe, że małopłytkowość u tego chorego była skutkiem nowotworu przebiegającego ze splenomegalią. U chorych ze sztuczną zastawką ryzyko powikłań zakrzepowo-zatorowych jest istotnie podwyższone w porównaniu z chorymi bez protez zastawkowych. Co ciekawe, w przebiegu HIT głównym objawem nie są krwawienia, ale incydenty zakrzepowo-zatorowe obejmujące łożyska tętnicze i żyıne [4]. W przypadku podejrzenia HIT przerwanie stosowania LMWH jest postępowaniem z wyboru. Należy jednak włączyć nieheparynowy lek przeciwzakrzepowy (bezpośrednie inhibitory trombiny lub heparynoidy). Ponowne rozpoczęcie leczenia VKA zaleca się w przypadku znaczącego wzrostu liczby PLT ( $\geq 100 \mu \mathrm{l} / \mathrm{I}$, a najlepiej $\geq 150 \mu \mathrm{l} / \mathrm{I})$ [5].

$\mathrm{U}$ opisanego chorego VKA włączono mimo bardzo niskiej liczby PLT ze względu na wysokie ryzyko zakrzepowo-zatorowe związane z obecnością protezy zastawkowej przewyższające ryzyko krwawienia. U osoby ze wskazaniami do leczenia przeciwzakrzepowego i z małopłytkowością bez sztucznej zastawki idealnym rozwiązaniem byłoby zastosowanie doustnych antykoagulantów niebędących antagonistami witaminy K (NOAC, non-vitamin K oral anticoagulants). Jednak w badaniu RE-ALIGN wykazano, że dabigatran stosowany u pacjentów po implantacji mechanicznej protezy zastawkowej nie jest równie skuteczny jak warfaryna w prewencji powikłań zakrzepowo-zatorowych, a ponadto jego stosowanie wiąże się z istotnie statystycznie zwiększonym ryzykiem powikłań krwotocznych [6].

\section{Podsumowanie}

Postępowanie u chorego z małopłytkowością i bezwzględnym wskazaniem do antykoagulacji, takim jak sztuczna zastawka, wymaga zindywidualizowanego leczenia uwzględniającego przede wszystkim bardzo wysokie ryzyko powikłań zakrzepowo-zatorowych.

\section{Konflikt interesów}

Autorki deklarują brak konfliktu interesów. 


\section{Abstract}

Thromboembolic complications such as systemic embolization and valve thrombosis are a major complications after mechanical valve replacement; however, the benefit of anticoagulation must be weighed against the risk of bleeding events. The management in a patient with thrombocytopenia and absolute indication for anticoagulation, such as mechanical heart valve, requires individualization of treatment taking into account a very high risk of thromboembolic complications.

Key words: thrombocytopenia, mechanical heart valve, thromboembolic complications

Folia Cardiologica 2016; 11, 3: 233-235

\section{Piśmiennictwo}

1. Vahanian A., Alfieri O., Andreotti F. i wsp. Guidelines on the management of valvular heart disease. Eur. Heart J. 2012; 33: 2451-296.

2. Butchart E.G., Ionescu A., Payne N. i wsp. A new scoring system to determine thromboembolic risk after heart valve replacement. Circulation 2003; 108: ॥68-II74.

3. Warkentin T.E., Greinacher A. Heparin-induced thrombocytopenia and cardiac surgery. Ann. Thorac. Surg. 2003; 76: 2121-2131.
4. Ortel T.L. Heparin-induced thrombocytopenia: when a low platelet count is a mandate for anticoagulation. Hematol. Am. Soc. Hematol. Educ. Program 2009: 225-232.

5. Hudzik B., Wasilewski J. Małopłytkowość poheparynowa. Folia Cardiol. Excerpta 2013; 8: 65-67.

6. Eikelboom J.W., Connolly S.J., Brueckmann M. i wsp. Dabigatran versus warfarin in patients with mechanical heart valves. N. Engl. J. Med. 2013; 369: 1206-1214. 